Noncommittal outcome

\section{Washington}

THE title "Anomalous effects in deuterated metals" hardly disguised the fact that a closed meeting in Washington last week was about cold fusion. The three-day workshop (16-18 October), organized by the National Science Foundation (NSF) and the Electric Power Research Institute (EPRI), an industry-based technology development association, brought together a remarkable collection of those who have seen "anomalous effects", including Stanley Pons and Martin Fleischmann. Also present were some sceptics, notably Nate Lewis of the California Institute of Technology. Getting these people together was no easy feat: at least two outspoken critics refused to attend because they saw little in the meeting but a parade of dubious and mostly well-known evidence for cold fusion, whereas one believer had to be persuaded that the workshop was not stacked with sceptics before he agreed to attend. And, contrary to usual NSF practice, the workshop was closed to the press.

According to Paul Werbos, programme director for Emerging Technologies in NSF's division of Electrical and Communication Systems, the workshop was meant to help NSF deal with a steady stream of grant applications for coldfusion experiments. Werbos consulted an NSF colleague on leave from EPRI, which has been supporting experiments at Texas A\&M University, and the idea was born of a jointly organized meeting, co-chaired by John Appleby of Texas A\&M and Paul Chu of the University of Houston, Texas.

Although some new data were presented at the meeting, a final statement issued to the press by Appleby gave no details, observing only that anomalous heating "appears to be real in many cases" and that there was reason to believe that the appearance of tritium in some electrolytic cells "is not an artefact". But others who attended the sessions said that no consensus was reached on any of the experimental results. No one denied that the detection of tritium was genuine, but several remained unconvinced that contamination had not been ruled out. And the claims of excess heat were as controversial as ever, with some saying that the calorimetry appeared to carefully done, while others decried a lack of controls and reproducibility.

Werbos emphasized that the purpose of the meeting was not to pass judgment but to decide what research ought to be done. Both sides in the debate seem to accept that the heat measurements will probably not prove convincing one way or the other, and that the presence or absence of nuclear products is the crucial evidence. To this end, Edward Teller of Lawrence
Livermore Laboratory suggested that partial replacement of palladium with uranium-235, which accepts neutrons readily, would help to determine if some kind of neutron transfer initiated by deuterium was at work.

In about a month, the proceedings of the NSF/EPRI workshop will be released, along with some recommendations for further research. This report should appear at about the same time as the conclusions of the Department of Energy's (DoE) special panel on cold fusion, a preliminary version of which recommended against putting any money into the area (see Nature 340, 174; 1989).

Thomas Schneider of EPRI did not accept the idea, put about by critics, that the purpose of last week's meeting was to provide a counterweight to the anticipated negative verdict of DoE's "killer commission", as John Bockris of Texas A\&M has dubbed it.

But if the aim was to find some common ground between believers and critics, the workshop had little success. Those who seem able to get anomalous results see a need for further research, and argue that one should not dwell on "negative" results because in those experiments, evidently, the conditions are not quite right for cold fusion to work. Critics, on the other hand, maintain that if you are allowed to keep positive results and throw away the rest you can never be proved wrong: it becomes, as one sceptic put it, religion, not science.

David Lindley

\title{
Speak softly or carry a big stick
}

Washington

FuELLING the debate over how to coordinate and finance international efforts to sequence the human genome, James Watson, director of the National Institutes of Health Center for Genome Research, said last

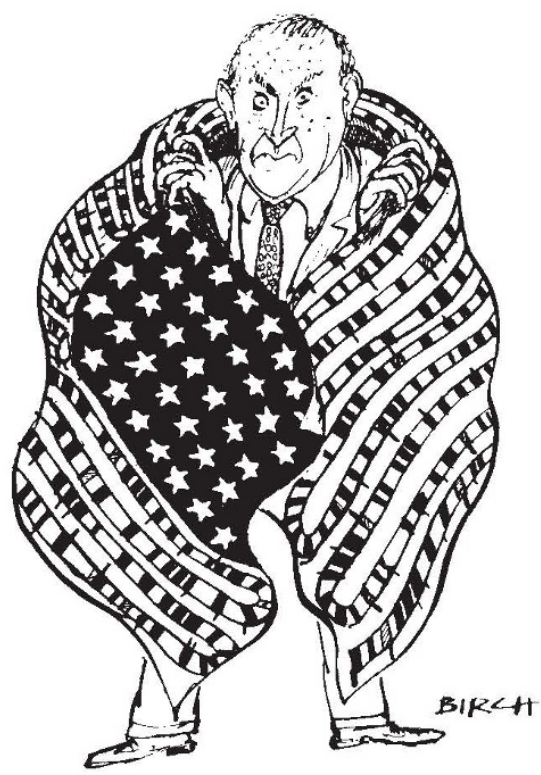

week that the United States should ensure that other countries support basic research by threatening to restrict access to its data. Testifying at a hearing of the House of Representatives subcommittee on international scientific cooperation, Watson declared that "America has been subsidizing the rest of the world for too long in science and it's time that [others] came in".

The subcommittee, set up three years ago to examine financing for 'big science' projects, is scrutinizing the $\$ 3,000$-million human genome project because of fears that the United States might end up subsidizing foreign biotechnology industries.
Watson confirmed these fears, saying it was possible that the United States would do all the basic research while others would focus on the commercial applications.

Although the United States could map and sequence the human genome alone, said Watson, "it makes sense to reduce the cost to the American public by some form of sharing". And a political reason for collaboration, Watson added, was that if the United States were to tackle the project alone, the prospect of one country claiming all rights to the data might put the rest of the world "ill at ease".

But instead of a multitude of bilateral agreements - such as the agreement between the UK Medical Research Council in Cambridge and Washington University Medical School in St Louis to sequence the nematode - Watson endorsed HUGO (the Human Genome Organization) as the vehicle to facilitate international collaborations. Although HUGO has been accused of inactivity, leading some to argue against contributing to it, Watson says supporting it will save the United States "a great deal". If other countries did not participate, he said, he would hold on to the US data "for quite a bit of time".

HUGO treasurer George Cahill, of the Howard Hughes Medical Institute (HHMI), said Watson was "playing hardball" and that he would favour "a more soft and more diplomatic" approach to encourage international genome mapping efforts. More countries want to join HUGO, he said, and will do so when it has "more stability and funding". Cahill says HUGO may begin to move more quickly within the next few weeks after it becomes a US corporation, which would allow it to receive a \$1 million gift that HHMI is considering. After that, "we could really have some clout and could get moving", says Cahill.

Christine McGourty 